\title{
The Impact of Development and Government Expenditure for Information and Communication Technology on Indonesian Economic Growth
}

\author{
Neli AGUSTINA*, Setia PRAMANA** \\ Received: August 27, 2019. Revised: September 18. Accepted: October 05. 2019.
}

\begin{abstract}
Purpose - This research is aimed to investigate the impact of the Information and Communication Technology (hereinafter ICT) development index and ICT investment on Indonesian economic growth.

Research design, data and methodology - The data used consist of ICT development index, government expenditure on ICT sector, and economic growth from 33 provinces in Indonesia from 2012 to 2015. Based on the Networked Readiness Index published by the World Economic Forum (WEF), Indonesia was ranked 80 $80^{\text {th }}$ among 142 countries in 2012 and had climbed $64^{\text {th }}$ in 2014. This indicates that the businesses in Indonesia have adopted ICTs to increase productivity and expand their activities. Panel data regression analysis is performed to reveal the change of the impact over time in each of the provinces.

Result - The ICT development index and government expenditure for ICT have a positive effect on the economic growth of all provinces, although the impact is different in each of the provinces. There is a digital gap between the provinces, especially the large digital gap occurring with DKI Jakarta. The provinces of Eastern Indonesia such as NTT and Papua are still relatively slow in development of ICT.

Conclusions - ICT development index and allocation of local government expenditure for ICT have significant effect on economic growth. ICT development index has a bigger role in increasing economic growth.
\end{abstract}

Keywords: Information and Communication Technology (ICT), ICT Development Index, Economic Growth, Panel Data Regression.

JEL Classification: 012, 033, 038.

\section{Introduction}

Currently, the development of Information and Communication Technology (ICT) has become one of the most important indicators determining the development of economy in a region. ICT has become a catalyst for economic growth, which can be seen from the widespread impact of the utilization-and enablement of the application of more efficient methods for the production, distribution and consumption of goods and services.

1 First Author, Politeknik Statistika STIS, Jakarta Indonesia 2 Corresponding Author, Politeknik Statistika STIS, Jakarta Indonesia. Tel: +62-812-9789-3257. Email: ririn.riez@yahoo.com (c) Copyright: Korean Distribution Science Association (KODISA) This is an Open Access article distributed under the terms of the Creative Commons Attribution NonCommercial License (https://creativecommons.org/licenses/by-nc/4.0/) which permits unrestricted noncommercial use, distribution, and reproduction in any medium, provided the original work is properly cited.
As an archipelago country, Indonesia has a geographical constraint. Hence, the development of ICT infrastructure plays important role to disseminate information more quickly and to support the distribution of development in each region.

However, the ICT infrastructure developments and utilization in Indonesia are still lagging behind as compared to its neighboring countries. Based on Network Readiness Index published by World Economic Forum-(WEF) in 2012, Indonesia is ranked $80^{\text {th }}$ among 142 other countries with index value of 3.75 , far away from the neighboring countries such as Malaysia (index=4.8, position 29) and Singapore (index=5.86, position 2). In 2014 Indonesia's network readiness index increased to 4.04 and ranked at $64^{\text {th }}$ position; whereas, Malaysia had index 4.83 and was in $30^{\text {th }}$ position. 
The ICT Development Index developed by the International Telecommunication Union (ITU) describes the level of development of information technology and communications of a region. The Indonesia's Information and Communications Technology Development Index has increased every year from 4.24 in 2012 to 4.83 in 2015 (Official Statistics News BPS, 2016). Increasing ICT development index indicates an increase in the utilization of ICT in increasing productivity and expanding economic activity in Indonesia.

One way to measure the impact of ICT development in national development is from the contribution of communication subsector to total GDP. In 2012, the contribution of the communications subsector was 6.39 percent and ranked $4^{\text {th }}$ largest after the industrial without oil and gas subsector (23.85 percent), the wholesale and retail trade subsector (15.12 percent), and the agriculture, livestock, forestry and fisheries subsector (6.52 percent).

In addition, the constant GDPs of the communications subsector consistently increased from 2000 to 2014, with $18,260.3$ billion rupiahs in 2000 to $205,957.2$ billion rupiahs by 2014 , as shown in Figure 1.

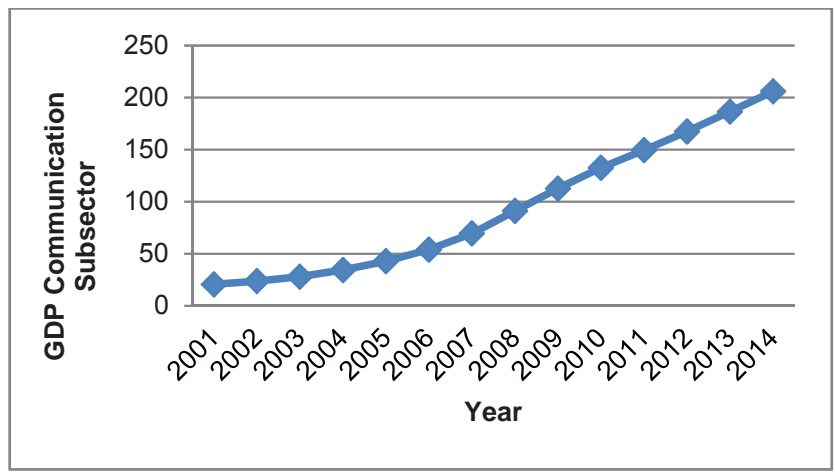

Figure 1: GDP Communication Subsector in 2000-2014 (Billion Rupiahs)

The large contribution of the communication subsector to GDP and the increase in GDP value of communications subsector indicates that ICT has an important role in the national economy. Based on this, ICT sector can be used as one of the key sectors in boosting economic growth in Indonesia (Azuari, 2010). Economic growth theories predict that economic growth is driven by the investments in ICT.

Basically, ICT development cannot be separated from the roles of government, society, and industry. The government, as policy holder, strategy, and priority on a region, has an important role in regional development. The sincerity of government in developing and improving ICT can be seen through the realization of government budget expenditure for ICT. Based on figure 2, it can be seen that the Indonesia government expenditure for ICT has been increasing every year.

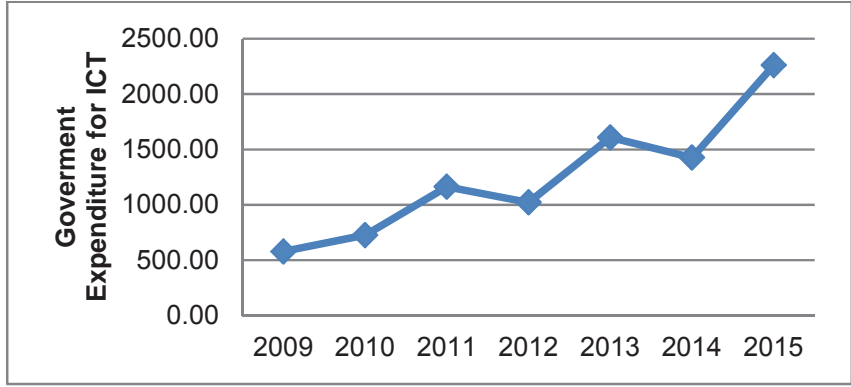

Figure 2: Government Expenditure for ICT in 2009-2015 (billions of rupiah)

According to Nata (2007), ICT investment has a strong influence on the growth of the Indonesian economy. High growth rates of investment will trigger a high Indonesian economic growth. Increased government expenditure in the technology and communications sector will have a major impact on capital production factors, corporate institutions and labor that play a role in boosting economic growth.

Since 2004, Indonesia has adopted a fiscal decentralization policy, in which each region has the authority to manage its own finances. The existence of policy differences in the allocation of regional expenditures will cause the development of ICT in each province to be different. The difference of ICT development between regions, can lead to digital divide between regions. Based on the Association of Internet Service Providers Indonesia (APJII), internet users in Indonesia increased rapidly from 88 million people in 2014 to 132.7 million in 2016 . However, most of the users (65 percent) are in Java.

Based on 2014 Village Potential data (Podes), not all provinces in Indonesia have adequate telecommunications infrastructure and telephone signal reception. In Java, 46.9 percent of villages already have a Base Transceiver Station (BTS), and 99.53 percent of villages have been covered by cell phone signals. Whereas, the percentage of villages in Papua and Maluku that have BTS and covered by cell phone signal is only 8.19 percent and 44.09 percent, respectively. This indicates an inequality or a gap in the ICT development between provinces in Indonesia known as digital gap. Based on the background and description discussed previously, the purposes of this study are: (1) to provide an overview of the development of provincial ICT development index and local government expenditure for ICT in Indonesia, (2) to provide overview of the digital gap between provinces in Indonesia, and (3) to investigate the impact of ICT development index and local government expenditure for ICT on economic growth. 


\section{Lliterature Review}

Nasab and Aghaei (2009), in their research, used a Generalized Method of Moments (GMM) within the framework of a dynamic panel data approach and applied it to the economy of OPEC member countries over the time span of 1990-2007. The estimates reveal a significant impact on economic growth of investments in ICT in the OPEC member countries. This implies that if these countries seek to enhance their economic growth, they need to implement specific policies that facilitate investment in ICT.

Zuhdi, Mori, and Kamegai (2012) addressed the role of ICT-sectors in contributing to structural changes in the national economies of Indonesia and Japan from 1995 to 2005. They showed that ICT sectors played an important role in the changes in Japan's economy but did not have a significant influence on structural changes in the economy of Indonesia.

Niebel (2014) studied the impact of ICT-on economic growth in developing, emerging and developed countries. The study was based on a sample of 59 countries for the period 1995 to 2010. Bongo (2005) showed that ICT has a large contribution to economic growth, where in the business process, the use of adequate technology can make the process faster-and cost-effective and increase the level of production.

In addition, Farhadi, Ismail, and Fooladi (2012) shows a positive relationship between the growth rate of real GDP per capita and ICT development index. A country with higher development of information technology has higher economic growth. In other words, there is a tendency that countries with a rapid ICT growth have a rapid economic growth as well.

Vu Khuong (2004) provides a cross-country view on this issue by assessing the impact of ICT on economic growth for 50 major ICT spending countries. The study shows that ICT investment has a significant impact on economic growth, not only as traditional investment, but also as a boost to efficiency in growth: a higher level of ICT capital stock per capita allows an economy to achieve a higher growth rate for given levels of growth in labor and capital inputs.

\section{Methodology}

\subsection{Data and Scope of Research}

The scope of this research covers 33 provinces in Indonesia for a period of 2012-2015. The data used in this study is obtained from Central Bureau of Statistics (BPS) Indonesia and Ministry of Finance Indonesia. The variables used in the reseach are as follows:
- Gross Regional Domestic Product (GRDP)

The economic growth in this research is approached through growth indicators of Gross Regional Domestic Product (GRDP).

- ICT development index at provincial level

The ICT development index is developed by International Telecommunication Union (ITU). ICT development index is a composite index that combines 11 indicators into a standard measure of information and communication technology development of a region. Data of ICT development index for 2012 to 2015 is obtained from Statistics Official Gazette (BRS) released by BPS on December 15, 2016.

- Local Government expenditure for ICT.

One of the roles of government in development can be seen from the amount of government expenditure which, in this case, can be reflected in the Regional Budget. The data of local government expenditure for ICTs referred to in this study is the realization of local government expenditure for ICTs.

\subsection{Regression Analysis of Panel Data}

This research used a panel data, which is a combination of cross section data and time series data. Cross section data were collected to examine the value of one or more variables from a sample unit at a time, while time series data were collected to examine the value of one or more variables over time (Gujarati, 2004). Models of data panel modeling can be written as follows:

$$
\begin{aligned}
& Y_{i t}=\beta_{0}+\beta_{1} \mathrm{X}_{1 i t}+\beta_{2} \mathrm{X}_{2 i t}+\cdots+\beta_{k} \mathrm{X}_{k i t}+\varepsilon_{i t} \\
& \varepsilon_{i t}=\mu_{i}+v_{i t}
\end{aligned}
$$

$$
\begin{aligned}
& \text { where, i : number of individuals } \\
& t \text { : time period of the study } \\
& \beta_{0} \text { : intercept coefficient } \\
& \beta \text { : slope coefficient } \\
& Y_{\text {it }} \text { : dependent variable for object unit i and unit } \\
& \text { time } t \\
& \mathrm{X}_{\mathrm{it}} \text { : independent variable for object unit i and unit } \\
& \text { time } t \\
& \varepsilon_{i t}: \text { component of interference } \\
& \mu_{\mathrm{i}}: \text { individual effect } \\
& \mathrm{V}_{\mathrm{it}} \text { : random variable }
\end{aligned}
$$

Estimation of parameters in panel data regression analysis can be done with three models: common effects model, fixed effects model and random effects model. Common effects model combines time series and cross section data in pool form, so that it is also called Pooled Regression Model (Gujarati, 2004). Common effects model 
does not see variations between individuals and times, in other words variation of models between individuals and times is assumed to be the same. Parameter estimation uses the Ordinary Least Square (OLS) method. Common forms of common effects models can be written as follows:

$$
Y_{i t}=\beta_{0}+\beta_{1} X_{1 i t}+\beta_{2} X_{2 i t}+\ldots+\beta_{k} X_{k i t}+v_{i t}
$$

where, $k$ : the number of explanatory variables used in the model

i: number of individuals,

t: time period.

Based on the assumption of residual variance covariance structure, there are three different estimation methods that can be used (Greene, 2003):

Ordinary Least Square (OLS), if the residual covariant structure matrix structuring is assumed to be homoscedastic and there is no cross sectional correlation

- Weighted Least Square (WLS): Cross Sectional Weight, if the residual covariance matrix structure is assumed to be heteroscedastic and there is no cross sectional correlation.

- Feasible Generalized Least Square (FGLS) / Seemingly Uncorrelated Regression (SUR), if the structure of its residual covariant-variance matrix is assumed to be heteroskedastic and there is a cross sectional correlation.

The fixed effects model assumes differences among individuals that can be accommodated through different intercepts. Parameter estimation for fixed effects model uses Least Square Dummy Variable (LSDV) technique. The regression equation is as follows:

$$
\begin{aligned}
Y_{i t} & =\beta_{0}+\beta_{1} X_{1 i t}+\beta_{2} X_{2 i t}+\ldots+\beta_{1} X_{k i t}+\mu_{i}+v_{i t} \\
& =\left(\beta_{0}+\mu_{i}\right)+\beta_{1} X_{1 i t}+\beta_{2} X_{2 i t}+\ldots+\beta_{1} X_{k i t}+v_{i t} . . \\
& =\alpha_{\mathrm{i}}+\beta_{1} X_{1 i t}+\beta_{2} X_{2 i t}+\ldots+\beta_{1} X_{k i t}+v_{i t}
\end{aligned}
$$

where, $\mathrm{k}$ : the number of explanatory variables used in the model,

i: number of individuals,

$\mathrm{t}$ : time period.

Based on the assumption of matrix structure of the residual variance covariance, there are 3 estimation methods that can be used in the fixed effects model (Greene, 2003):

Ordinary Least Square (OLS / LSDV), if the structure of its residual covariant-variance matrix is assumed to be homoscedastic and there is no cross sectional correlation.

- Weighted Least Square (WLS) or Generalized Least Square (GLS), if the structure of its residual covariant- variance matrix is assumed to be heteroskedastic and does not have cross sectional correlation.

- Seemingly Uncorrelated Regression (SUR) or Feasible Generalized Least Square (FGLS), if the structure of its residual covariant-variance matrix is assumed to be heteroskedastic and there is a cross sectional correlation.

The random effects model estimates panel data in which error variables may be interconnected between time and between individuals. Differences between individuals and/or time are accommodated through error (Nachrowi \& Usman, 2006). In this model, we use estimates, where errors may be correlated between time and between individuals, so OLS cannot be used to obtain an efficient estimator. The appropriate method to estimate this model is Generalized Least Square (GLS) with homoscedastic assumptions and no cross-sectional correlation (Greene, 2003). The basic equation of the random effect model is:

$$
Y_{i t}=\beta_{0}+\beta_{1} \mathrm{X}_{1 i t}+\beta_{2} \mathrm{X}_{2 i t}+\cdots+\beta_{k} \mathrm{X}_{k i t}+\varepsilon_{i t}
$$

where,

$$
\varepsilon_{i t}=\mu_{i}+v_{i t}
$$

Since, in the random effects model, OLS estimates cannot be used due to $\sigma_{v}^{2}, \sigma_{\varepsilon}^{2} \neq 0$, Generalized Least Squares (GLS) is then implemented.

In order to test the significance of fixed effects model using the $\mathrm{F}$ test statistic or Chow test-statistic. Chow test is used to find out whether the technical regression of panel data with fixed effects is better than panel data regression using pooled model. Hypothesis used is as follows:

$$
\begin{aligned}
& \mathrm{H}_{0}: \mu_{1}=\mu_{2}=\ldots=\mu_{n}=0 \text { (pooled model), } \\
& \mathrm{H}_{1}: \text { There is at least one of } \mu_{i} \neq 0 \text { for all } i=\mathrm{i}, 2, \ldots, \mathrm{n} \\
& \text { (fixed effect model). }
\end{aligned}
$$

It can be carried out using the following Chow test statistic which follows the Fisher distribution,

$$
F=\frac{\left(R S S_{2}-R S S_{1}\right) /(n-1)}{R S S_{2} /{ }_{(n t-n-k)}} \sim F(n-1 ; n t-n-k)
$$

Breusch-Pagan Lagrange Multiplier (LM) test can be used to find out whether the random effects model is better than the common effects model (Greene, 2003). It test the following hypothesis:

$\mathrm{H}_{0}: \sigma_{\mu}=0$ (pooled model),

$\mathrm{H}_{1}: \sigma_{\mu} \neq 0$ (random effect model) 
The Breusch-Pagan Lagrange Multiplier (LM) test statistic defined below follows the chi-square distribution,

$$
L M=\frac{n t}{2(t-1)}\left[\frac{\sum_{i=1}^{n}\left(\sum_{t=1}^{T} \hat{\varepsilon}_{i t}\right)^{2}}{\sum_{i=1}^{n} \sum_{t=1}^{T} \hat{\varepsilon}^{2}{ }_{i t}}-1\right]^{2} \sim X^{2}(\alpha, n-1)
$$

Next is to determine the appropriate model between fixed effects or random effects, by testing the following hypothesis (Greene, 2003):

$\mathrm{H}_{0}: \operatorname{cov}\left(\varepsilon_{\mathrm{it}}, \mathrm{X}_{\mathrm{it}}\right)=0$ (REM),

$H_{1}: \operatorname{cov}\left(\varepsilon_{i t}, X_{i t}\right) \neq 0$ (FEM).

It can be carried out using the following Hausman test statistic which follows the chi-square distribution,

$$
\begin{aligned}
W= & \left.\chi^{2}[K]=\left[\hat{\beta}_{F E M}-\hat{\beta}_{R E M}\right]^{\prime}\left[\operatorname{var} \hat{\beta}_{F E M}-\hat{\beta}_{R E M}\right)\right]^{-1}\left[\hat{\beta}_{F E M}-\hat{\beta}_{R E M}\right] \\
& \sim X^{2}(\alpha, k)
\end{aligned}
$$

After common effects or fixed effects model is selected, the structure of the variance-covariance matrix needs to be evaluated to determine the appropriate estimation method used in the model (whether OLS, GLS, or FGLS methods). Once the best model is obtained, it is necessary to check the classical assumption, consisting of normality, homoscedasticity, non-autocorrelation, and nonmulticollinearity.

\subsection{ICT Development Index}

ICT Development Index is an indicator that can describe the level of development of information and communication technology in a region. The higher index value indicates that the development of ICT of an area is increasing rapidly-and vice versa, meaning, the lower index value indicates the development of ICT in a region is relatively slow. The ICT Development Index is useful for comparing ICT development across time and between regions. It can show the digital gap and the potential development of ICT. The calculation is based on the methodology of the International Telecommunication Union (ITU), in which there are 11 IPICT compiler indicators that are grouped into 3 sub-indexes, namely, access and infrastructure sub-index, expert subindex and usage sub-index.

BPS' Statistics Indonesia uses three categories in conducting provincial groupings in the ICT development index: low, medium, and high. The low category is the province that has an ICT development index below the average. The high category is above the ideal values (average $(\mu)+2$ standard deviation), and medium category is between the average and ideal values.

\subsection{Economic Growth}

Economic growth is defined as an increase in the ability of an economy to produce goods and services. Economic growth is one of the most important indicators in analyzing the economic development occurring in a country or region. Economic growth can be assessed as the impact of government policies, especially in the economic field. The growth of the regional economy in general can be seen through the growth indicators of Gross Regional Domestic Product (GRDP). Capital (through savings and investment), labor (changes in the number of workers), and changes technology are the factors that determine economic growth.

Along with the development of knowledge and the era of globalization, innovation, as the discovery of new products or production efficiency of existing products, has led to the emergence of changes in technology. Information and Communication Technology (ICT) is the most rapidly growing technology globally, which is characterized by the emergence of various innovations, and the technology has become part of infrastructure for various sectors of life. All countries in the world will not be able to avoid the bias of Information and Communication Technology (ICT). Both developed and developing countries, including Indonesia, have placed ICT as one of the main drivers of economic growth.

\subsection{Government Expenditure for ICT}

ICT Investment by the Minister of Communication and Information Technology Number 41 Year 2007 is a budget management process for ICT investment purposes. Management of ICT investment is carried out through the mechanism of preparation of activity plan and budget of an institution, along with other fields, in accordance with relevant regulation (Minister of Communication and Information Regulation Number 41/2007). There are two types of expenditures in ICT investment budgets (Minister of Communication and Information Regulation Number. 41/2007):

1. Operational Expenditure (OpEx). ICT Operating Expenditure (OpEx) is the expenditure of ICT in order to maintain the level and quality of service. The OpEx includes salary \& overtime fees, tool rental fees, overhead costs, ATK and others.

2. Capital expenditure (CapEx) of ICTs is an investment in the form of ICT assets/infrastructure necessary to deliver, expand and/or improve the quality of public services. The CapEx includes construction / purchase of networks, servers \& PCs, software, buildings, and land use. 
The government's commitment to the progress of ICT can be seen through the realization of government budget spending on ICT, which continues to increase. This shows the seriousness of the government in the development of ICT. ICT investment in Indonesia has a strong influence on Indonesia's economic growth, and high levels of ICT investment growth have triggered Indonesia's high economic growth.

\section{Results}

\subsection{ICT Development Index}

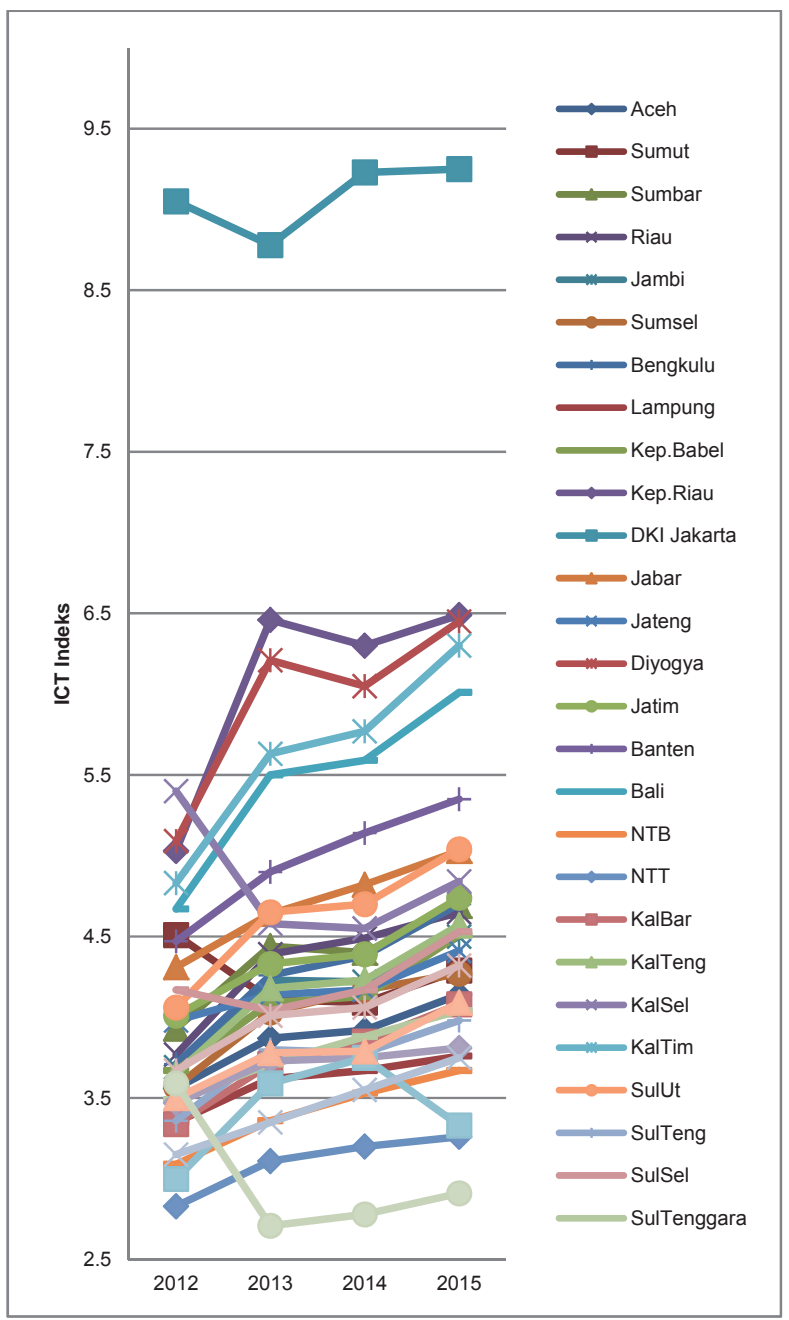

Figure 3: ICT Development Index of Provincial in Indonesia Period $2012-2015$

In general, the ICT development index for all provinces in Indonesia has increased but is still relatively low, the index value is still much below 5 , as shown in figure 3 . The province with the highest ICT index for 2012-2015 is Jakarta. The second highest ICT is Riau, though the index is much lower than Jakarta. Furthermore, the provinces with the lowest value of ICT development index during the study period are NTT and Papua. This shows large gap in ICT development across provinces. The ICT development index of most provinces in Indonesia is lower than the national average. It can be seen that most of the provinces have lower ICT index from 2,5 to 4,5 .

Figure 4 presents the ICT index categories of all provinces. Only Jakarta (blue) has high index, and the rest of the provinces have medium (blue light) and low (green) development index. Furthermore, we can see that Bengkulu and East Java have improved the ICT developments from Low to Medium category. While the ICT Development Index of North Sumatera has changed from medium to low category.

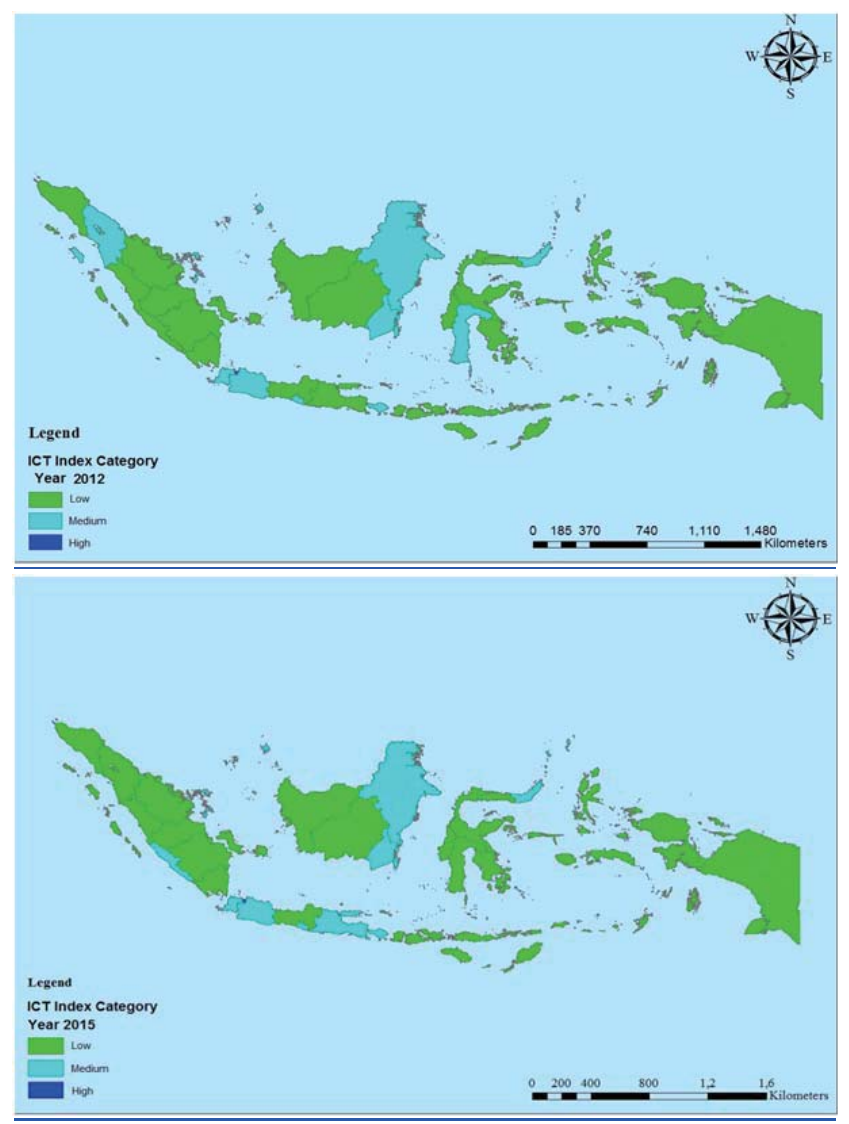

Figure 4: Grouping of ICT Development Index in 2012 and 2015

\subsection{Development of Local Government Expenditure for ICT}

ICT development cannot be separated from the government role and its regulation. The seriousness of the 
government in the development and advancement of ICT can be seen through the realization of government expenditure for ICT development, which continues to increase. As shown in Figure 5, local government expenditure for ICT (Billion Rupiahs) on average increases during the study period. Some provinces such as Jakarta, East Java, West Java and NTB have allocated higher local government expenditure for ICT than other provinces.

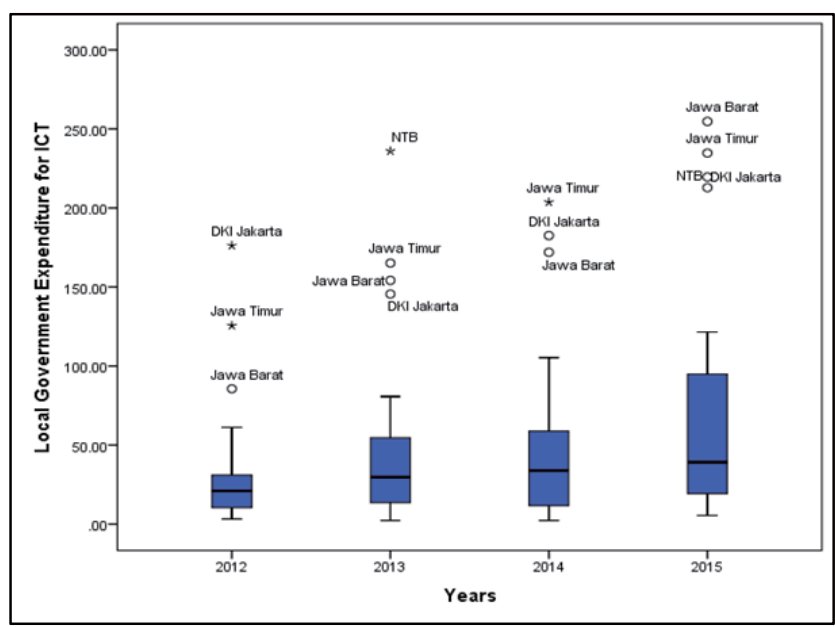

Figure 5: Local Government Expenditure for ICT(Billion Rupiahs)

However, when we observe the ratio of ICT expenditure to total government expenditure, local government expenditure for ICT is still relatively very small as compared to other expenditures in most of the provinces, as shown in Figure 6 . The ratio of government expenditure for ICT is still very low. Most of the provinces have ratio below $0,5 \%$. Only East Java, Central Java and NTB have ratio of ICT expenditure that is more than $1 \%$.

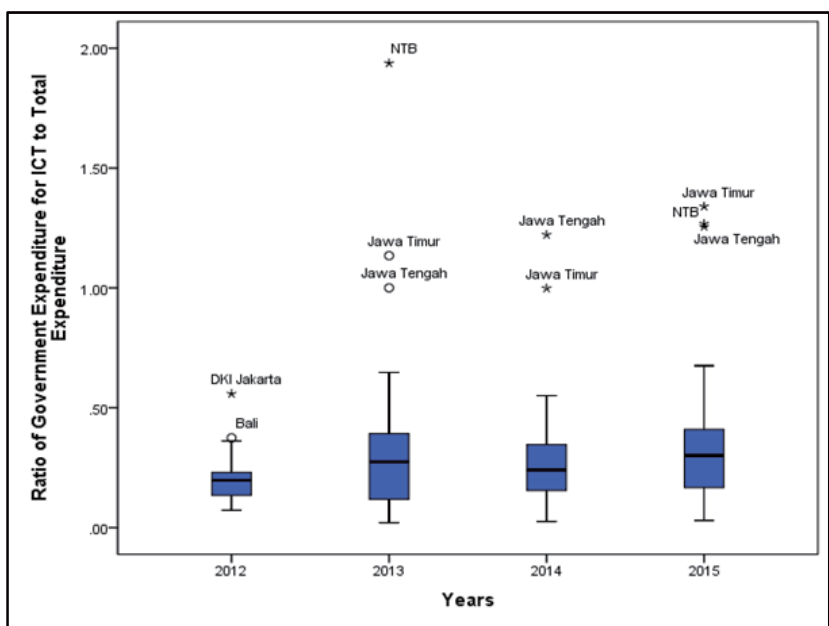

Figure 6: Ratio of Goverment Expenditure for ICT to Total Expenditure Period 2012-2015
Figure 7 shows a positive correlation between the ICT development index and the local government expenditure on ICT. Provinces with higher local government expenditure on ICT and higher ICT development index-should have higher economic growth. Jakarta has higher local government expenditure on ICT with higher ICT development index, and, as can be seen in figure 7, Jakarta, in quadrant 1 , has higher Gross Regional Domestic Product (blue) too. Jakarta has a large gap with the other provinces. Most of the provinces with lower local government expenditure have lower Gross Regional Domestic Product/ GRDP (red). Most provinces in eastern Indonesia have lower local government expenditure on ICT and lower ICT index. Surprisingly, Nusa Tenggara Barat (NTB) allocates high local government expenditure on ICT, though it has low regional gross domestic product (GRDP) and low ICT development index. It shows that this province has invested a lot on ICT to boost its economic growth but still has low economic growth. Provinces with lower expenditure and lower ICT index, which still have lower Gross Regional Domestic Product, need to review allocation their expenditure for ICT and development of their ICT utilization.

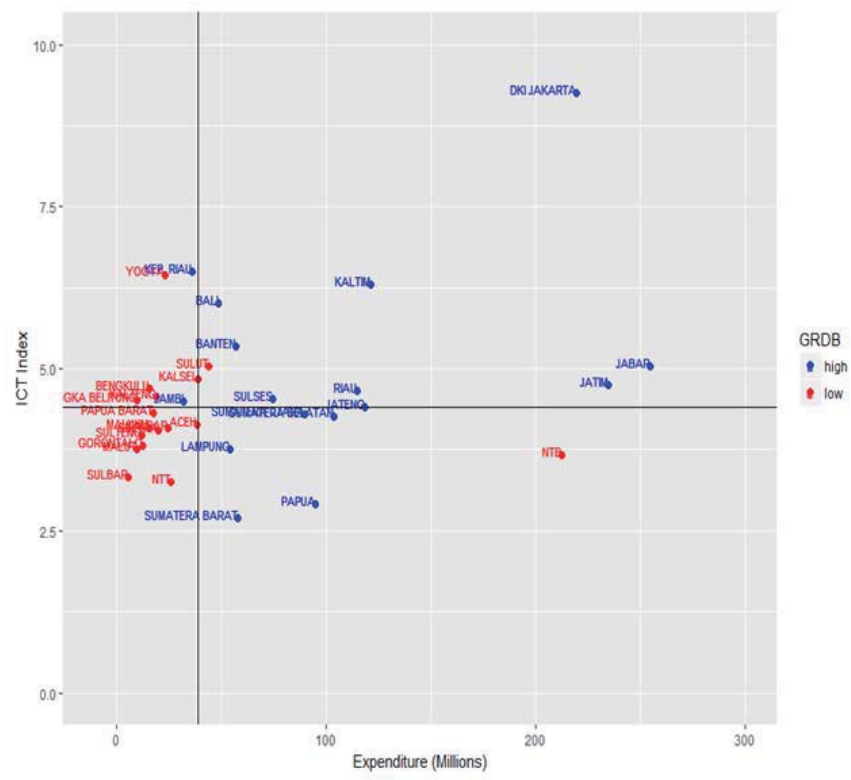

Figure 7: Quadrant Analysis Local Government Expenditure with ICT Development Index in 2015

\subsection{The Impact of Development and Local Government Expenditure for ICT on Indonesia Economic Growth}

The analytical method used to determine the impact of development and local government expenditure for ICT on 
Indonesia economic growth. The Chow test was used to choose the model between common effects model (CEM) and fixed effects model (FEM). The results of Chow test indicate that $\mathrm{H}_{0}$ is rejected at the 5 percent significance level (Table 1). This shows that FEM is better than CEM. The next test is the Hausman test. Hausman test is used to choose the model between fixed effects model and random effects model (REM). The results of Hausman test indicate that $\mathrm{H}_{0}$ is rejected at the 5 percent significance level (Table 1). This shows that FEM is better than REM. Furthermore, the Lagrange Multiplier (LM) and Lamda LM tests suggest, respectively, heteroscedastic structure of residual variancecovariance, and there is correlation between residual provinces model.

Table 1: The Output of Chow test and Hausman Test

\begin{tabular}{|c|c|c|c|}
\hline Test & Statistic & d.f. & Prob. \\
\hline Chow Test & 478.752059 & $(32,97)$ & $<0.00001$ \\
\hline & 669.044557 & 32 & $<0.00001$ \\
\hline Hausman Test & 143.330108 & 2 & $<0.00001$ \\
\hline
\end{tabular}

Therefore, the selected model is a fixed effects model with cross-sectional weight and cross-section SUR. The results are summarized in Table 2.

Table 2: The Estimates of fixed Effects Models with Heteroscedastic and Cross-Sectional Correlation (Seemingly Uncorrelated Residual)

\begin{tabular}{|c|c|c|c|c|}
\hline Variable & Coefficient & Std. Error & t-Statistic & Prob. \\
\hline Intercept & 16.68009 & 0.228606 & 72.96427 & $<0.00001$ \\
\hline ICT Index & 0.088648 & 0.016758 & 5.289967 & $<0.00001$ \\
\hline Ln(expenditure) & 0.091728 & 0.015205 & 6.032724 & $<0.00001$ \\
\hline $\mathrm{R}^{2}$ & 0.998717 & Prob(F-statistic) & $<0.00001$ \\
\hline Adjusted $\mathrm{R}^{2}$ & 0.998267 & Durbin-Watson stat & 2.12728 \\
\hline
\end{tabular}

The result shows that the ICT development index and local government expenditure for ICT significantly affect the economics growth. The result is in accordance with the results of the study of Bongo (2005) and Azuari (2010), which show that ICT development index has an effect on economic growth. The adjusted $\mathrm{R}^{2}$ shows that 99.83 percent of the variation in provincial economic growth rates in Indonesia is determined by the ICT development index and the local government ICT expenditure, and the rest is determined by other factors.

Based on the selected model, an increase in one unit of ICT development index-can increase economic growth by 0.089 percent, assuming other variables are constant. It shows the impact of information and communication technologies (ICT) on economic growth. A region with higher development of information technology has higher economic growth. In other words, there is a tendency that regions with a rapid ICT growth have a rapid economic growth as well.

In addition, the increase in 1 percent in local government expenditure for ICT would expect to increase economic growth by 0.092 percent, assuming other variables are constant. ICT investment has a strong influence on economic growth. High growth rates of investment will trigger a high economic growth. Increased local government expenditure in the technology and communications sector will have a major impact on capital production factors, corporate institutions and labor that play a role in boosting economic growth.

Table 3: Individual Effect of Provinces in Indonesia

\begin{tabular}{|c|c|c|c|c|c|}
\hline No & Provinsi & Effect & No & Provinsi & Effect \\
\hline 1 & Aceh & -0.05189 & 18 & NTB & -0.41058 \\
\hline 2 & North Sumatra & 1.138885 & 19 & NTT & -0.71727 \\
\hline 3 & Sumbar & 0.010778 & 20 & West Kalimantan & -0.08852 \\
\hline 4 & Riau & 1.161867 & 21 & Central Kalimantan & -0.46449 \\
\hline 5 & Jambi & -0.05386 & 22 & South Kalimantan & -0.23572 \\
\hline 6 & Sumsel & 0.580144 & 23 & East Kalimantan & 1.184506 \\
\hline 7 & Bengkulu & -1.18761 & 24 & North Sulawesi & -0.70023 \\
\hline 8 & Lampung & 0.421302 & 25 & Cental Sulawesi & -0.40203 \\
\hline 9 & Kep.Babel & -0.95583 & 26 & South Sulawesi & 0.558400 \\
\hline 10 & Kep.Riau & 0.001398 & 27 & Southeast Sulawesi & -0.52046 \\
\hline 11 & Jakarta & 1.783494 & 28 & Gorontalo & -1.64181 \\
\hline 12 & West Java & 2.007780 & 29 & West Sulawesi & -1.39544 \\
\hline 13 & Central Java & 1.710597 & 30 & Maluku & -1.55508 \\
\hline 14 & Yogyakarta & -0.55825 & 31 & North Maluku & -1.68626 \\
\hline 15 & East Java & 2.116985 & 32 & West Papua & -0.78952 \\
\hline 16 & Banten & 0.917730 & 33 & Papua & 0.007273 \\
\hline 17 & Bali & -0.18627 & & & \\
\hline
\end{tabular}

The fixed effects model assumes that differences between individuals (cross section) can be accommodated from the differences in their intercepts. There is influence of individual effects, as shown in Table 3. Jakarta and some provinces in Java have an individual effects that are higher than others provinces. It means that economic growth of Jakarta and some provinces in Java is better than other provinces when there is no change in other variables.

\section{Discussion}

Economic growth can occur in two ways, first by increasing land use, labor and capital-and secondly, through better use of technology to improve productivity from existing capital and labor resources. Using ICT in the production of goods with computerized systems can shorten production time. Service using ICT will also be faster and more efficient. Economic growth is also related to the area 
of a region, as larger regions require greater economic activity. Indonesia is an archipelago country, which has a very wide area. So-ICT development can simplify economic activities.

ICT development cannot be separated from the role of government. The government contributes in developing and promoting ICT through the allocation of government expenditure for ICT. Through a close relationship with other sectors of the economy, government expenditure on the communications sector has a big role and influence on the national economy. The increased government expenditure for ICT sector will have a major impact on capital production factors, corporate institutions and labor that play a role in boosting economic growth.

The differences in ICT development index and regional policies in managing their local expenditure for ICT can affect the region's economic growth gap. The better the ICT development index and the greater the allocation of local government expenditure for ICT sector, the higher the economic growth will be.

\section{Conclusions}

The ICT development index of every province in Indonesia show an increase, but most provinces are still in the low category. Only Jakarta is included in the high category. Some provinces have improved the ICT developments from Low to Medium category. Allocation of local government expenditure for ICT sector, in general, has increased for each year. However, in terms of share to total expenditure area, the ratio of local government expenditure for ICT sector is still very low under 1 percent. There is a digital gap between provinces, especially the large digital gap occurring with DKI Jakarta. The provinces of Eastern Indonesia such as NTT and Papua are still relatively slow in development of ICT. ICT development index and allocation of local government expenditure for ICT have significant effect on economic growth. ICT development index has a bigger role in increasing economic growth. Local government should pay more attention to improve ICT development, by simplifying the regulation of ICT investment that can encourage the increase of ICT development. Local government should start to increase-the allocation of expenditures for ICT and regulate-its expenditure to the right target, thereby impacting on improvements in other sectors and of course can be boosting economic growth.

\section{References}

Azuari, S. (2010). The Impact of ICT Spending on Indonesia's Economy. Jakarta, Indonesia: University of Indonesia.

Bongo, P. (2005). The Impact of ICT on Economic Growth. Munich, Germany: University Library of Munich.

BPS' Statistics Indonesia (2016). Telecommunication Statistics Indonesia 2015.

BPS' Statistics Indonesia (2014). Data Collection of Village Potential.

BPS' Statistics Indonesia. (2016). Official Statistics News (BRS). Retrieved May 22, 2019, from https://bps.go.id/website/brs-ind-2016121531927.pdf.

Farhadi, M., Ismail, R., \& Fooladi, M. (2012). Information and Communication Technology Use and Economic Growth. PLOS ONE, 7(11), e48903. doi:10.1371/ journal.pone.0048903

Greene, W. H. (2003). Econometric Analysis (5th Ed). Upper Saddle River, NJ: Prentice Hall.

Gujarati, D. N. (2004). Econometric Analysis (4th Ed). Singapore: McGraw Hill.

Michael Edison Nata. (2007). The Impact Analysis of ICT Investment Toward National Economic in Indonesia. Jakarta, Indonesia: University of Indonesia.

Minister of Communication and Information Regulation. Number 41 of 2007.

Nachrowi, N.D., \& Usman, H. (2006). Pendekatan Populer dan Praktis Ekonometrika Untuk Analisis Ekonomi dan Keuangan. Jakarta, Indonesia: University of Indonesia.

Nasab, E. H., \& Aghaei, M. (2009). The Effect of ICT on Economic Growth: Further Evidence. Tehran, Iran: International Bulletin of Business Administration.

Niebel, T. (2014). ICT and Economic Growth - Comparing Developing, Emerging and Developed Countries. Paper presented at the IARIW 33rd General Conference, Rotterdam, Netherlands.

OECD (2003). ICT and Economic Growth.

$\mathrm{Vu}, \mathrm{K}$. (2004). Measuring the Impact of ICT Investments on Economic Growth. Journal of Economic Growth.

Zuhdi, U., Mori, S., \& Kamegai, K. (2012). Analyzing the role of ICT sector to the national economic structural changes by decomposition analysis: The case of Indonesia and Japan. Social and Behavioral Sciences, 65(3), 749-754 